\title{
The discourse of NKRI (The Unitary State Republic of Indonesia) and caliphate in the Indonesian context
}

\section{Wacana NKRI (Negara Kesatuan Republik Indonesia) dan khilafah dalam konteks Indonesia}

\author{
Siti Kholifah \\ Department of Sociology, Faculty of Social and Political Sciences, Universitas Brawijaya \\ Address: Jalan Veteran, Lowokwaru, Malang, East Java 65145 \\ E-mail: ifah_sosio@ub.ac.id
}

Article History: Received 3 September 2019; Accepted 20 August 2020; Published Online 6 September 2020

\begin{abstract}
This study's primary focus is to examine the discourse of the NKRI (Unitary State of the Republic of Indonesia) and that of the caliphate that has been developing on social media. It involves essential issues because Indonesia's state and religion have had a dynamic relationship since the New Order era. The debatable issue related to the state and religion shows that religion is a crucial subject used to maintain the state. As a state, Indonesia emphasizes multicultural values; however, some people or organizations have an intolerance of Indonesia's plurality promoted on social media. Using Foucault's theory on discourse, power, and knowledge, this study was conducted by applying big data to Social Network Analysis (SNA) through the netlytic program. Big data is a new method developed to analyze the social phenomena that happen in the digital era. This study examines the assumption that the discourse of the NKRI is not a single discourse in the Indonesian context. It is in addition to the caliphate's discourse, although the NKRI is still the dominant discourse. The debatable issue within the discourse of the NKRI and the caliphate is related to dynamic religious organizations that are not based on cultural values. They tend to be either puritan (seeking to purify the doctrine) or radical. This situation is also related to the political context where the caliphate's discourse is developing related to Jakarta's local election. There is also the issue of the religious defamation conducted by Basuki Tjahaja Purnama (Ahok). This situation explains the increase in Islamic political roles that are not affected by the sociological context. The roles are more impacted by political elites who are using religion as a political vehicle.
\end{abstract}

Keyword: discourse; NKRI; caliphate; social media

\section{Abstrak}

Fokus utama penelitian ini adalah mengkaji wacana NKRI (Negara Kesatuan Republik Indonesia) dan khilafah yang berkembang di media sosial. Hal ini merupakan masalah penting karena negara dan agama di Indonesia memiliki hubungan yang dinamis sejak masa Orde Baru. Perdebatan isu antara negara dengan agama menunjukkan bahwa agama merupakan subyek penting dalam mempertahankan negara. Sebagai negara, Indonesia menekankan nilai-nilai multikultural; namun, kondisi ini dihadapkan dengan beberapa orang atau organisasi yang tidak toleran terhadap pluralitas di Indonesia, yang itu dimunculkan di media sosial. Dengan menggunakan teori Foucault tentang wacana, kekuasaan dan pengetahuan, penelitian ini menggunakan metode big data dengan Social Network Analysis (SNA) melalui program netlytic. Big data merupakan metode baru yang dikembangkan untuk menganalisis fenomena sosial yang terjadi dalam dunia digital. Hasil penelitian ini menunjukkan bahwa wacana NKRI bukan wacana tunggal yang ada Indonesia, tetapi ada juga wacana khilafah meskipun NKRI masih menjadi wacana dominan. Perdebatan wacana NKRI dan khilafah terkait dengan dinamika organisasi keagamaan yang tidak didasarkan pada nilai-nilai budaya, tetapi cenderung pada nilai-nilai puritan (memperjuangkan kemurnian doktrin) atau radikal. Selain itu, situasi ini juga terkait dengan konteks politik dimana wacana khilafah berkembang terkait dengan Pilkada di Jakarta, dan masalah penistaan agama yang dilakukan Basuki Tjahaja Purnama (Ahok). Hal ini menunjukkan bahwa peningkatan peran politik Islam tidak dipengaruhi oleh konteks sosiologis, tetapi cenderung dipengaruhi oleh elit politik yang menggunakan agama sebagai kendaraan politik.

Kata kunci: wacana; NKRI; khilafah; media sosial 


\section{Introduction}

The relationship between religion and the state has always been an extended matter of debate. The discussion on the topic began when the founding fathers formed the Indonesian state. They based the foundation of the country on creating a balance in various aspects of life. The debate over the state and religion's position shows that religion is essential when establishing and maintaining its integrity. The thought of religion's importance in a country shows that this country avoids the secularism that separates religion from political affairs. Secularism considers politics not to be sacred, it underlies the separation of the spiritual and religious components regarding politics because it can inhibit political and social changes. This understanding is certainly in contrast with the Indonesian ideology. Secularism shows there to be an absence of human morality when dealing with religion and society. It is along with the idea of Yusuf Qardhawi, one of the Muslim clerics in Indonesia. He stated that the erosion of religion from politics through secularism means being apart from pure values, rejecting evil, and letting society be controlled by evil elements instead. In this case, religion is a form of social control when carrying out the country's social and political life as a whole (Supriyadi 2015).

As the foundation and ideology of the Indonesian state, Pancasila places religion as something significant, and this is marked by the first principle of "God the Almighty," however, in this case, Indonesia is not a country that prioritizes a particular religion as the most superior from among the other acknowledged religions. In accordance with the first principle of Pancasila, the citizens of Indonesia express their belief in God the Almighty. The journey to determine this ideology has experienced a prolonged debate since some political figures expect a country based on Sharia Islam. Based on the nation's historical sources, the first Islamic groups or organizations in Indonesia, such as the Indonesian Islamic State or Negara Islam Indonesia (NII), were accused of being disappointed with the formation of an Indonesian state that was not based on Islam's teachings. The debate in terms of the shape of the Islamic state and law has accompanied the Indonesian people's journey since Independence Day (van Bruinessen 1996, van Bruinessen 2002, Mueller 2008, Bourchier 2019). People who support Indonesia in their prioritization of national unity and the foundation of the Indonesian Republic have decided to define Indonesia as a state based on the religious and moral principles instilled in the Pancasila (van Bruinessen 2002, Al-Rasheed et al. 2012). Some organizations have taken part in building the country based on several aspects of Pancasila, namely Muhammadiyah and Nahdlatul Ulama (NU).

In the New Order era, the caliphate discourse stopped; however, after the Suharto Regime in 1998, there was a democratization period and reduced political control. It was used by the puritan or radical groups to spread their purpose in Indonesia, such as Islamic Defenders Front or Front Pembela Islam (FPI), Hizbut Tahrir Indonesia (HTI), Islamic Da'wah Council or Majelis Dakwah Islamiyah (MDI), Indonesian Islamic Da'wah Institute or Lembaga Dakwah Islam Indonesia (LDII), and Indonesian Muslim Student Action Unit or Kesatuan Aksi Mahasiswa Muslim Indonesia (KAMMI). FPI and other organizations are making attempts to fight for Islam comprehensively so that Islam becomes the basis of state law, the state's foundation and the political system with an orientation focused on Salafi practices (Zada 2002). FPI encourages the development of Sharia law in Indonesia, and HTI strongly believes that the implementation of Sharia law must be carried out in conjunction with re-establishing the caliphate (Ahnaf 2009, Muhtadi 2009, Munabari 2017). Almost the Islamic organizations in this period supported the implementation of Sharia law in Indonesia that was assumed to solve the financial crisis in Asia that had been ongoing since 1997. The Islamic state was assumed to be the central concept used to encourage more equitable social and economic interests (Osman 2010, Hadiz 2011, Munabari 2017). The caliphate's discourse was utilized as an indicator to debate the context of the economic, social, and political injustices. As a result, the caliphate's whole concept is unclear (Al-Rasheed et al. 2012, Munabari 2017).

In President Susilo Bambang Yudhoyono era, more than 150 regulations based on Sharia law were enacted at the district and city level in 2011. Salafi groups proliferated in Indonesia and promoted a concept of exclusive Islamic citizenship (Bourchier 2019). Although some Islamic organizations desire to build the caliphate, in the Reform Era, the Islamic political orientation became radical 
(Joebagio 2016). This situation is different from the previous Islamic organizations that have accepted Pancasila and the Republic of Indonesia in its entirety. This condition has made the meaning of being Indonesian diverse in terms of perception. Moreover, there were "411 Movements" taking place on $4^{\text {th }}$ November 2016 and " 212 Actions" on $2^{\text {nd }}$ December 2016 pioneered by FPI. These are considered to be due to the assumption that Basuki Tjahaja Purnama (Ahok) had committed blasphemy in Seribu Islands when he conducted a work visitation (Debora 2016). When he socialized the program in Seribu Islands, Ahok was accused of blasphemy towards Islam by being offensive to verse 51 of AlMaidah. There is still a debate on the interpretation of the verse, HTI also supports the prosecution and punishment of Ahok in terms of his blasphemy (Fajerial 2016).

The issue of Indonesia ensuring the emphasis on plurality in the nation seems to be an exciting discussion. It has become a new journey for Indonesia while facing some parties regarding diversity that has been declared to be Bhinneka Tunggal Ika (unity in diversity) by the founding fathers. Aside from this issue, other parties display intolerant behaviors directed towards the diversity in the country and the concepts of being Indonesian that relate to this. There have been many intolerant issues presented on social media such as Twitter, Instagram, and Facebook. This condition is caused by the Indonesian government, not censoring, monitoring, or restricting the social media platforms used in the country. As a result, Indonesia is an ideal internet field for radical groups (Richey \& Binz 2015). Some radical organizations use social media to spread their agenda and encourage their members to attend their digital activities (Osman 2010). This study investigates and analyzes the discourse of the NKRI and the caliphate in the Indonesian framework. In addition to the use of data on social media, such as Twitter, it is experiencing a significant development regarding the issues tied into the condition of being Indonesian through the netlytic program.

This study utilized the discourse based on Foucault's context in which discourse is understood to be a rule. The practice creates something meaningful, and it is regulated throughout the historical period. Discourse provides the language necessary to deliver the statements and strategies used to represent a particular topic's knowledge. It is seen as a form of knowledge production through language because social practices need meaning. Discourse is the organized and organizing practices that can shift the social constellation and create something with autonomy and claims toward the truth and its associated contexts. Discourse is a central concept drawn from Foucault's analysis that emphasizes something that people say and think about, and the things said with the power and authority that they possess (Ball 1990). Discourse is relevant to the social process produced where the meaning is not only derived from the language but also the relationship between the power and institution involved. The discourse also allows for new perspectives on religion where power is formed between one religious group and others, and between the majority and minor ones.

Foucault (1988b) stated that "power is productive," it is a product of knowledge, and it is constructed through class domination. Foucault (1988a) asserted that power produces knowledge rather than repression, and power is not merely a harmful matter. It also creates a level of expectation (Foucault 1980). In accordance with Foucault's discussion, power is strongly linked to an individual's discourse and knowledge. The ones playing the most prominent role in establishing knowledge are the power holders (Haryatmoko 2016). Foucault mentioned that what is assumed to be "right," is not something that has always been "there," it does not remain untouched by the time it has been found. He added that something that is right intrinsically is tied to the relationship among the discourses used by humans to express the truth, the system of power that is considered valid, and the status of the involved subjects. The dominant discourse is connected with the practices of institutionalization, control, law, and disciplinary organizations. The forms of discourse also represent existing historical knowledge; however, it is both disguised as and disqualified by the dominant discourse. Power and discourse are directly related as they are two sides of the same coin. The relationship of power is only present when there is the correlative existence of knowledge. No discourse does not simultaneously indicate or base itself on the power relations present. 


\section{Research Method}

This research has utilized the big data method as its chosen approach. In big data, what is referred to as data is the information interpreted by a particular person who has a limited relationship with the researcher. However, data is also concerned with social behavior and information in the digital world and the human interactions through online media (Golder \& Macy 2014). The primary characteristic of big data is a considerable quantity of data because it is based on the compilation and accumulation of community interactions in cyberspace or on social media. Data can come from all digital sources. Based on social media, the data is differentiated based on the user-generated content categories (Pozzi et al. 2016). User-based profiles found on Facebook and Myspace, microblogging is based on shared messages such as on Twitter, and there is also content-based data such as on YouTube, Flickr, and Instagram.

In this study, the primary data was sourced explicitly from Twitter, where the netlytic program supported the data collection. Much of the data were then grouped according to several principal characteristics that will become the essential findings to be analyzed in this research. Generally, the data characteristics that can be accepted are $5 \mathrm{Vs}$ and $1 \mathrm{C}$. It refers to volume (size and quantity of the data), velocity (variation in the rate and direction of the data), variety (format types of the data), variability (varied consistency from time to time), veracity (variation or differences in the quality of the data), and complexity (data coming from various sources) (Yusainy et al. 2017). In practice, big data generally only involves $3 \mathrm{Vs}$; volume, velocity, and variety (Laney 2001). In volume, it assumes that the data was considered massive data in the past and not as large data in the present or now. It is also assumed that it will be small data in the future, and it is caused by extensive data storage technology getting smaller over time. Velocity refers to the rate and quickness of the data itself. Velocity is the assumption that digital devices are capable of doing the tracking and recording process quickly and on time. Finally, variety refers to the heterogeneous data-set structures (Shilpa \& Kaur 2013).

There are four forms of data structure in big data: 1) unstructured, referring to the data that does not have a coherent structure in the form of text, audio, or video, 2) quasi-structured, referring to various data formats still in a defined ecosystem, 3) semi-structured, referring to the data with settled patterns with varied content, and 4) structured data, which is the data with a clearly-defined format. Based on the various data structure types, $80-90 \%$ of the data growth in the future is dominated by unstructured data (EMC Education Service 2015). This research used the unstructured data in the form of text taken from the accumulation of messages or community interactions about the caliphate's discourse and the NKRI through microblogging, such as Twitter. The below stages make up the research method that was carried out.

The data was collected from Twitter using the https://netlytic.org program into which the related keywords on the concepts of being Indonesia (NKRI, multicultural, caliphate, and Islamisation) were inserted. These words were deliberately chosen to examine the discourse on the condition of being Indonesian, and the data was collected from Twitter between $10^{\text {th }}$ May and $8^{\text {th }}$ August 2017. The words appeared on the screen were categorized based on the time and the direction of the religious organization. The coding of the period and the direction was connected to mapping the organizational or institutional networks related to the observed religious organizations. The analysis technique used in this research was the Social Network Analysis (SNA). In big data, SNA is used to learn about entire networks. All connections contain a relationship within a particular population or private network, and several people determine their relationships. In the process, SNA is used to learn about the dynamics of interaction among social network users. It is because social media users' positions with other actors can be identified by looking at the scale and perspective of the digital text. In the network pattern, information propagation does not come from any one person anymore before moving downward. It has already become part of a network topology where the users are related to one another (interdependent). 


\section{Results and Discussion}

\section{Discourse contention of the caliphate and NKRI}

Based on Twitter's data about the caliphate and the NKRI, some essential facts are related to the time of posting and which Twitter accounts dominated the pronounced words. Additionally, the data also showed both the positive and negative sentiments on the relevant words. This chapter of the study elaborates on the discourse and counter-discourse findings concerning the keywords caliphate and NKRI. During the period of the data collection, there were 1.327 messages and 1.087 posters. The following graph shows that the words caliphate and NKRI reached their peak of being the most frequently posted about $13^{\text {th }}$ May 2017 by as many as 270 posts. The words' intensity experienced a dynamic trend and finally increased from $29^{\text {th }}$ May 2017 until July in the same year.

The words caliphate and NKRI were most commonly posted in May, along with the alleged blasphemy issue raised by some fanatic Islamic organizations against Ahok. $9^{\text {th }}$ May 2017 was the reading time for the legal decision on Ahok, and he was sentenced to two years in prison. After that day, there was debate relating to the appeal made by Ahok and his prosecutors in the trial; however, Ahok decided to withdraw the appeal on $29^{\text {th }}$ May 2017, whereas the prosecutors decided to continue it. Based on the above context, the keywords caliphate and NKRI were widely posted on the $13^{\text {th }}, 15^{\text {th }}, 17^{\text {th }}$, and $29^{\text {th }}$ May 2017 (Figure 1). The most frequently used words were caliphate with 1.278 mentions, and the second most common was NKRI, with 1.112 mentions (Figure 2).

Source Data: \# of Posts over Time - Embed Save Image

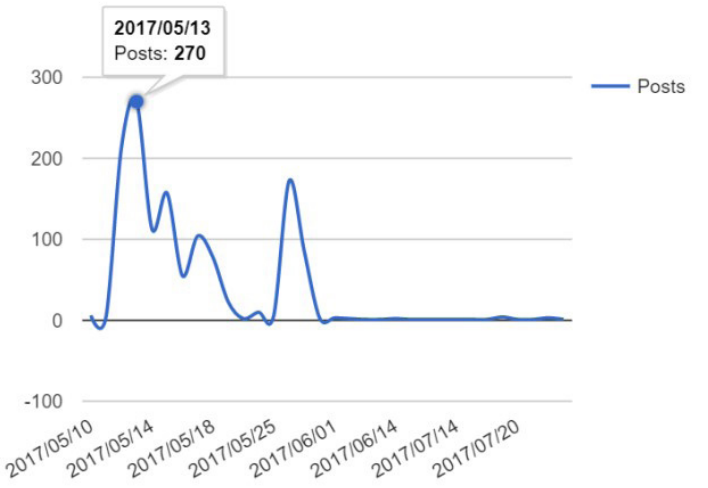

Figure 1.

Posts over time with the keywords caliphate and NKRI

Source: https://netlytic.org/index.php?do_fviz\&fid=82888

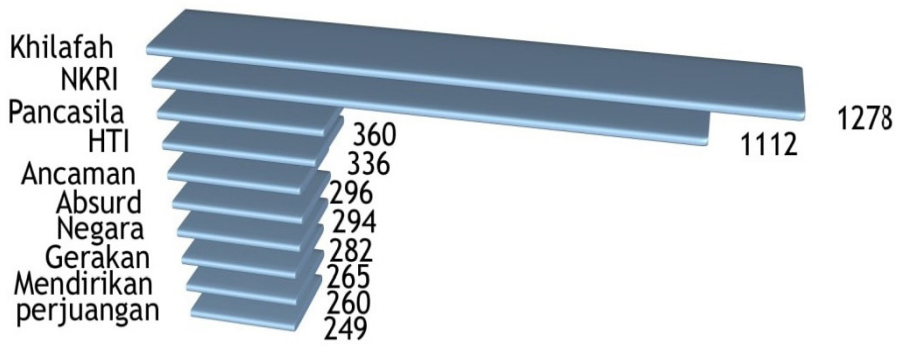

Figure 2.

Top ten most frequently used words

Source: https://netlytic.org/index.php?do_fviz\&fid=82888

The caliphate issue is also concerning the HTI, it is alleged to be a trans-nationalist organization that wants to replace the NKRI and Pancasila with the caliphate. HTI is a transnational organization that was founded by Taqiyyuddin an-Nabhani in 1953 in Jerusalem. In the early 1980s, HTI entered Indonesia; however, they only declared there to be a struggle to uphold the caliphate after the New Order's fall. HTI has a principle of non-violence when it comes to fighting to establish an Islamic 
caliphate (Mujahiduddin 2013). Baran (2004) explained that the ideology of HTI tends to omit acts of violence in the name of religion that is carried out by other radical Islamic groups. HTI's famous figures are M. Ismail Yusanto and Felix Siauw. Felix Siauw is well-known by young people and students through the books he has published and marketed by Gramedia.

The discourse of being Indonesian has become a very heated contestation among Twitter users that are connected with radical Islamic movements, namely the HTI and FPI. They wish to apply the caliphate concept in Indonesia that is also allegedly supported by Amanat Nasional Party (PAN) and Keadilan Sejahtera Party (PKS). This situation was also applied to the alleged blasphemy that Ahok accused without mentioning the Gerakan Indonesia Raya Party (Gerindra) in the issue. The caliphate's discourse has been spread out lately by Islamic fanatics, and it is countered by keeping the faith in Indonesia as espoused by the NKRI. The counter-discourse was conducted by the Twitter accounts that entitle themselves as individuals or institutions who have agreed to dismiss the fanatic Islamic movements, even though other mentions not support the dismissal. People who support the NKRI are fully aware that the caliphate issue has been around for a long time. It has been raised by radical organizations and some puritan political parties. The issue of Komunis Indonesia Party (PKI) is considered to be a vehicle to smooth the journey for the caliphate. PKI is not only regarded as a latent danger but also as an organization for atheists. This reason strengthens Islam's values and finally reinforces some of the other movements that support the caliphate.

The caliphate issue is also linked to the case of Ahok, who accused of blasphemy. It is relevant to many posts on the caliphate issue and NKRI in May when Ahok was waiting for the decision to be made in his trial. People who support the caliphate's idea believe that the present regime is repressive, so there is a vital necessity to change among the caliphate's supporters. The caliphate is also considered to make Indonesia stronger and more powerful. In this context, the caliphate's discourse is a process used to build the eastern stigma against the west. According to Huntington (1996), the east stigmatizes the west as the atheist, imperialist, and individualistic. Meanwhile, the west stigmatizes the east as uneducated immigrants. The context of the caliphate has become a new model of imperialism.

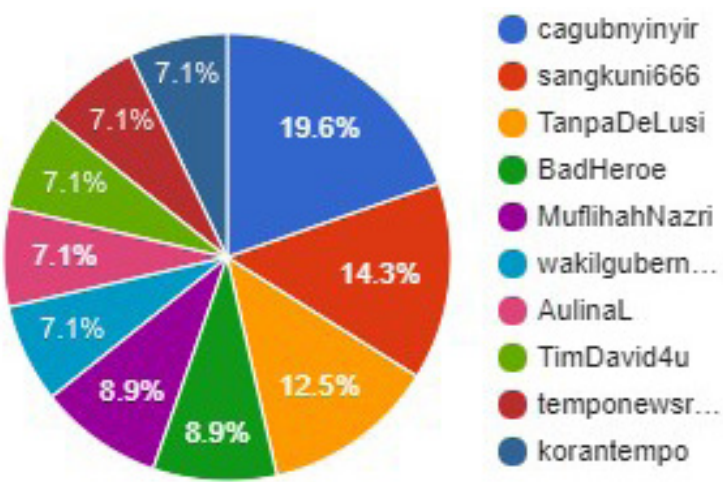

Figure 3.

Top ten posters for the keywords caliphate and NKRI

Source: https://netlytic.org/index.php?do_fviz\&fid=82888

From the top ten posters regarding the keywords caliphate and NKRI, cagubnyinyir's account is among the top posters (Figure 3). The account of cagubnyinyir is not only among the top ten posters regarding the keywords caliphate and NKRI; however it is also among the top ten posters mentioned in messages related to the keywords caliphate and NKRI (Figure 4). There was the same situation found for the account of tanpadelusi. The posts from the accounts of the top ten posters are more dominant regarding the issue of the NKRI and they criticize others by stating that some of the groups supporting the caliphate are merely political vehicles. The caliphate supporters counter this dominant discourse as it is not in the main cluster and remains a side group.

Based on Figure 4, seven posters are cagubnyinyir's network: tony wibowo, triwul82, sarah_pndj, fpurwatmo, engkongniy, and abdillahviking. The account fpurwatmo is connected with tanpadelusi and wakilgubernurkw, while supertoleran is linked to polhukamri, which is also in the central 
cluster. It indicates the networks' circle among the top ten Twitter accounts mentioned. Even when cagubnyinyir was not mentioned as much as tanpadelusi, the other mentioned accounts are still a part of it. Based on Figure 5, cluster one with the most involved number of networks (270 total degrees) refers to tanpadelusi (blue), followed by cagubnyinyir (yellow), polhukamri (red or beside the yellow one), teddygusnaidi (green or below the blue), and badheroe (red or next to the blue). The five clusters are present in the leading network; however, when tracked, the posts in tanpadelusi were all removed. Cagubnyinyir has a more complex network than tanpadelusi, in which all of the top ten mentioned have a relationship with it. Tanpadelusi is a single account that was retweeted or mentioned by many of its followers. The other followers, in turn, did not mention these followers.

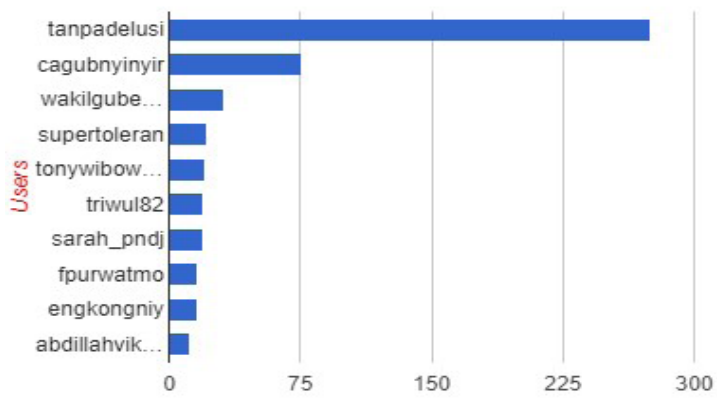

Figure 4.

Top ten posters mentioned in the messages related to the keywords caliphate and NKRI

Source: https://netlytic.org/index.php?do_fviz\&fid=82888

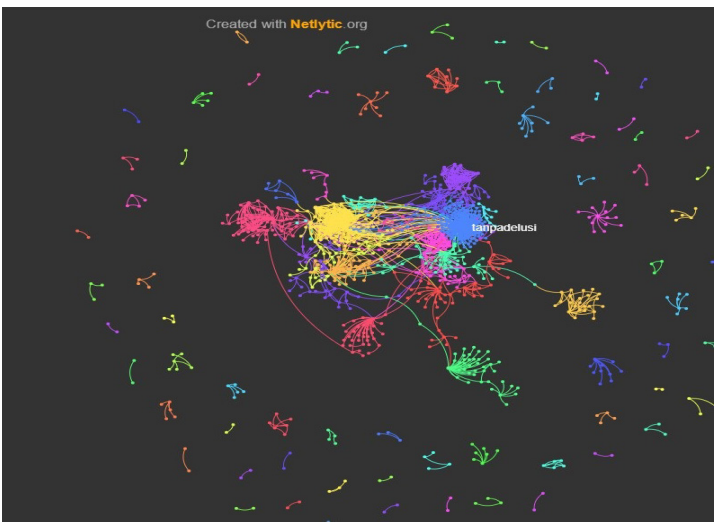

Figure 5.

The mention of the condition of being Indonesian issue using the keywords caliphate and NKRI

Source: https://netlytic.org/index.php?do_net\&fid=82888

\section{The condition of being Indonesian in the political and sociological discourse}

The NKRI and caliphate have been debatable in their relevance to blasphemy that Ahok accused, and it is also related to the Islamic puritan movement; NKRI counters the caliphate's discourse. This discourse battle has become more vital as the Jakarta election has increasingly displayed itself as being at the center of Indonesia's political map. Ahok is Chinese descent, and he was one of the candidates for the governor in Jakarta, competing against Anies Baswedan of Arab descent. This situation explains how the Islamic puritan movement gained a place in Indonesian politics. It asserted that there was a reduced level of political control after the New Order era. It was used by puritan Islamic groups to spread and develop their purpose in Indonesia, one of which is HTI (Mueller 2008, Osman 2010). According to one of the HTI leaders, the point of HTI is to select a few people to provoke a change effect. All people must be educated about the caliphate, so when the time comes for the caliphate to appear, they will encourage it (Osman 2010). The NKRI and the caliphate have been part of a discourse tied into the battle related to the condition of being Indonesian. After the New Order, the strong Islamic puritans have brought about differences in the political activity engaged in Indonesia. In 1999, the election was dominated by Islamic parties; however, the votes were still powered by nationalist parties, such as Demokrasi Indonesia Perjuangan Party (PDIP), Golongan 
karya Party (Golkar), and Kebangkitan Bangsa Party (PKB). Islamic parties such as PAN and PKS have got significant votes, and they are struggling with the role of winning over the public concerning their candidates for the election. Nevertheless, the political barometer in Indonesia is still Jakarta; it is not only the representation of the capital city; however, also the symbol of political strength for the 2019 presidential election.

The issue of religion in the Jakarta election has pointed out that all parties, not to mention the Islamic ones, in particular, use religion as a political vehicle. The strength of Islamic puritans was mobilized against the issue of blasphemy conducted by Ahok. The patriotic symbols surrounding the protest undoubtedly reflect politicians' priorities, such as Prabowo and Susilo Bambang Yudhoyono (SBY), who allegedly provided funding for the demonstration to increase Muslims' anger and the antiChinese sentiment. It was in order to increase public support for their party (Bourchier 2019), and the issue was successful at making Anies Baswedan and Sandiaga Uno the winners of the election in Jakarta. It was because the protest also portrayed the struggle of two Muslims to maintain a sense of nationalism by embracing the core of Indonesian life, namely the Constitution of 1945, Pancasila, and the NKRI (Bourchier 2019). It is a negative signal in Indonesia's democracy journey concerning how religion is politically transactional in terms of achieving power. It can be repeated in the elections every year, where the political elites will use the issue of religion to gain power. Moreover, the mobilization of Islamic groups during the Jakarta election of 2017 increased their impact dramatically where the radical groups cooperated with the conservative nationalists that asserted veto power over the process of the democratic figures and the constitution (Bourchier 2019).

The people who made some posts on both the caliphate and the NKRI have more than 5.000 followers. This condition has affected the spread of discourse on the caliphate and the NKRI in society. Additionally, the Twitter accounts related to the discourse are all linked to each other, so it is seen how they tweet something that can be connected to the broader scope of other accounts. It is also due to the number of followers tweeted about the caliphate and NKRI, which totaled above 5.000. The stronger the Islamic parties, the more reliable the discourse on the condition of being Indonesian. Both the NKRI and the caliphate's discourse occurred quite frequently because of the Jakarta election's political context. The debate in terms of the discourse of the caliphate has been mostly conducted on social media. It is because the puritan or radical groups assume that in the digital era, the semi-populist approach is essential to use to introduce and spread the caliphate's discourse, which is purposed to influence the people to accept their ideas without someone having to become a member (Osman 2010).

Frequently, the issues of the caliphate in South-East Asia, including those manifest in Indonesia related to social and economic injustice as well as political issues, means that the caliphate is utilized as an ideal state discourse by some Islamic organizations in Indonesia (Hadiz 2011, Al-Rasheed et al. 2012). Moreover, technology and the media have an impact when it comes to spreading the caliphate's discourse more widely (Al-Rasheed et al. 2012). The Intelligence Community has also asserted that extremist groups have grown more rapidly and increasingly sophisticated by using the internet. Currently, the domain of terrorism and warfare is not only on the land, air, and sea however also on the internet (Richey \& Binz 2015). In this research, we have explained the debatable issues between the caliphate and the NKRI as they are engaged with through Twitter, where the most frequently used word during this study was caliphate (Figure 2). Social media is a field of contestation fought over by the caliphate and the NKRI in Indonesia.

This condition also indicated that political elites play the relationship between religion and the State more. It is in line with Liddle's (1997) thesis, saying that a more substantial Islamic political role is not caused by a sociological trigger, but rather by the dynamics of the political elites to whom religion is merely a political vehicle. Sociologically the values of Islam in Indonesian society are more substantial than those during the New Order. It can be symbolically represented by the wearing of hijab by female Muslims. Hijab is a set of varied values, for female Muslims joining radical Islam, the hijab is seen as a form of opposition towards the present regime. It refers to the adoption of the values and style of female Muslims in the Middle East. For female Muslims living in an urban area, 
the hijab is a symbol of modern Islam paired with a more stylish and fashionable appearance, and in a rural area, the hijab is a display of Islam's cultural values.

The structural and political Islamic movements are mostly engaged by political elites or particular groups to gain structural strength at the national level. It can be observed from the case in the Jakarta election where religion arose before and after the election took place as a topic of discussion. Right after the governor inaugurated, any movement with the spirit of fighting for Islam was gone, and there were no posts about it on social media. This situation strengthens Liddle's (1997) thesis, stating that the political trigger of Islam is not based on the sociological context but more on the political battles played by the political elites and/or select parties. Both religious and non-religious parties use religion as a talking point and issue of focus to win political battles.

\section{Conclusion}

The NKRI, with Pancasila's foundation, no more solely voices the discourse on the condition of being Indonesian. Even though the NKRI has been the dominant discourse posted about on Twitter, there is also the caliphate's discourse that has been constructed by some individuals or groups of people even though they are not in the central cluster. The battle between the NKRI and the caliphate is closely connected with the dynamics of religious organizations that are not only cultural; however, also puritan or radical within the political context. The alleged blasphemy started the issue of the caliphate by Ahok.

Both groups, pro-NKRI and the pro-caliphate, have been attempting to make their discourse the one that is more dominantly seen. The Twitter accounts supporting the caliphate have tried to counter the positive sides to the robust discourse of the NKRI. The caliphate's supporters have gone public with their identity and ideology on social media as part of an effort to make their discourse bigger. In the digital era, social media has a significant role in winning the dominant discourse's position. In addition, the more substantial role of Islamic politics is not caused by a sociological trigger. Instead, it is due to the dynamics of the political elites who use religion as a political vehicle; however, sociologically, the values of Islam in society are now a lot stronger than those during the New Order. This context has strengthened Islamic politics at the temporary elites who seek to achieve a particular political purpose.

\section{References}

Ahnaf MI (2009) Between revolution and reform: The future of Hizbut Tahrir Indonesia. Dynamics of Asymmetric Conflict 2 (2):69-85. https://doi.org/10.1080/17467580902822163.

Al-Rasheed M, Kersten C, \& Shterin M (2012) Demystifying The Caliphate. New York: Oxford University Press.

Ball S (1990) Introducing Monsieur Foucault. In: Ball S (ed). Foucault and Education: Disciplines and Knowledge. London and New York: Routledge.

Baran Z (2004) Hizbut-Tahrir: Islam's Political Insurgency. Washington: Nixon.

Bourchier DM (2019) Two decades of ideological contestation in Indonesia: From democratic cosmopolitanism to religious nationalism. Journal of Contemporary Asia 49 (5):713-733. https://doi.org/10.1080/00472336.2019.1590620.

Debora Y (2016) Kronologi kasus dugaan penistaan agama. [Accessed 18 March 2017]. https://tirto. id/kronologi-kasus-dugaan-penistaan-agama-b457.

EMC Education Service (2015) Data Science and Big Data Analytics: Discovering, Analyzing, Visualizing and Presenting Data. Indianapolis: Wiley.

Fajerial E (2016) Ahok diperiksa Bareskrim, Hizbut Tahrir bereaksi, Tempo, 7 November. [Accessed 18 March 2017]. https://nasional.tempo.co/read/818219/ahok-diperiksa-bareskrim-hizbuttahrir-bereaksi/full\&view $=$ ok.

Foucault M (1980) Power/Knowledge: Selected Interviews and Other Writings, 1972-1977. Suffolk: The Harvester Press. 
Foucault M (1988a) Madness and Civilization: A History of Insanity in the Age of Reason. New York: Vintage Books.

Foucault M (1988b) Politics, Philosophy, Culture: Interviews and Other Writings, 1977-1984. New York: Routledge.

Golder SA \& Macy MW (2014) Digital footprints: Opportunities and challenges for online social research. Annual Review of Sociology 40 (2014):129-152. https://doi.org/10.1146/annurevsoc-071913-043145.

Hadiz VR (2011) Indonesian political Islam: Capitalist development and the legacies of the cold war. Journal of Current Southeast Asian Affairs 30 (1):3-38. https://doi. org/10.1177/186810341103000101.

Haryatmoko H (2016) Membongkar Rezim Kepastian: Pemikiran Kritis Post-Strukturalis. Yogyakarta: PT Kanisius.

Huntington SP (1996) The Clash of Civilizations and the Remaking of World Order. London \& Sydney: Simon \& Schuster.

Joebagio H (2016) Membaca politik Islam pasca reformasi. Jurnal Agastya 6 (1):1-8. http://doi. org/10.25273/ajsp.v6i01.867.

Laney D (2001) 3D data management: Controlling data volume, velocity and variety. META Group Research Note 6 (2001):70-73.

Liddle RW (1997) Islam, Politik dan Modernisasi. Jakarta: Pustaka Sinar Harapan.

Mueller AG (2008) The image of the other as enemy: A case study of Islamic fundamentalism and the "context of conflict" in Indonesia. Review of Communication 8 (2):123-126. https://doi. org/10.1080/15358590701772275.

Muhtadi B (2009) The quest for Hizbut Tahrir in Indonesia. Asian Journal of Social Science 37 (4):623-645. https://doi.org/10.1163/156853109X460219.

Mujahiduddin (2013) Menakar komitmen peaceful way Hizbut Tahrir Indonesia dalam konsolidasi demokrasi. Jurnal Ma'arif Insitute 8 (2):55-71.

Munabari F (2017) Reconciling sharia with "Negara Kesatuan Republik Indonesia": The ideology and framing strategies of the Indonesian forum of Islamic society (FUI). International Area Studies Review 20 (3):242-263. https://doi.org/10.1177/2233865917699066.

Osman MNM (2010) Reviving the Caliphate in the Nusantara: Hizbut Tahrir Indonesia's mobilization strategy and its impact in Indonesia. Terrorism and Political Violence 22 (4):601-622. https:// doi.org/10.1080/09546553.2010.496317.

Pozzi FA, Fersini E, Messina E, \& Liu B (2016) Sentiment Analysis in Social Network. Cambridge, MA: Morgan Kaufman.

Richey MK \& Binz M (2015) Open source collection methods for identifying radical extremists using social media. International Journal of Intelligence and Counter Intelligence 28 (2):347364. https://doi.org/10.1080/08850607.2014.962374.

Shilpa \& Kaur M (2013) Big data and methodology-a review. International Journal of Advance Research in Computer Science and Sofware Engineering 3 (10):991-995.

Supriyadi C (2015) Relasi Islam dan negara: Wacana Keislaman dan Keindonesiaan. Kalimah: Jurnal Studi Agama dan Pemikiran Islam 13 (1):199-221.

van Bruinessen M (1996) Islamic State or State Islam? Fifty Years of State-Islam Relations in Indonesia. In: Wessel I (ed). Indonesien am Ende des 20: Jahrhunderts. Hamburg: AberaVerlag.

van Bruinessen M (2002) Genealogies of islamic radicalism in Post-Suharto Indonesia. South East Asia Research 10 (2):117-154. https://doi.org/10.5367/000000002101297035.

Yusainy C, Kholifah S, \& Chawa AF (2017) Social data analytics sebagai metode alternatif dalam riset psikologi. Buletin Psikologi 25 (2): 67-75. https://doi.org/10.22146/buletinpsikologi.27751.

Zada K (2002) Islam Radikal: Pergulatan Ormas-ormas Islam Garis Keras di Indonesia. Jakarta: Teraju. 